\title{
Inferred summer precipitation for southern Ontario back to AD 610, as reconstructed from ring widths of Thuja occidentalis
}

\author{
Brendan M. Buckley, Robert J.S. Wilson, Peter E. Kelly, Douglas W. Larson, \\ and Edward R. Cook
}

\begin{abstract}
We present a network of seven ring-width chronologies of eastern white-cedar (Thuja occidentalis L.) from the Niagara Escarpment in southern Ontario, Canada. Using principal component regression, a 350-year June-July precipitation reconstruction (SOR) is developed for the region. Prior to the 20th century, the SOR series shows reasonable coherence, particularly at the decadal scale, with an independent tree-ring-based reconstruction of the Palmer drought severity index (PDSI) for roughly the same region. A weakening of the tree-growth - climate relationship in recent decades results in a regression model explaining $21 \%$ of the variance in the original climate series when the recent data are used for calibration. We therefore compromise with a model, calibrated for the period 1900-1960, which explains $33 \%$ of the variance. The model, while not terribly strong, does pass verification tests, indicating some degree of predictive skill. The longest chronology in our network, the 2787-year Flowerpot Island (FLOW) chronology, also exhibits common variability with the PDSI reconstruction, particularly on decadal and longer time scales and was used to infer hydroclimatic conditions back to AD 610. The combined information of the SOR, PDSI, and FLOW series suggests that dry conditions existed for the periods 1700-1725, 1750-1800, and 1840-1900, and wet conditions for the periods 1675-1700, 1730-1750, and 1810-1840. Over longer time scales, the FLOW chronology shows that summer precipitation was particularly variable during the 7 th, 9 th, 13 th, and 16 th centuries.
\end{abstract}

Résumé : Les auteurs présentent un réseau composé de sept courbes dendrochronologiques du thuya occidental (Thuja occidentalis L.) provenant de l'escarpement du Niagara dans le sud de l'Ontario, au Canada. À l'aide de la régression en composantes principales, ils ont reconstitué les précipitations en juin et juillet depuis 350 ans (SOR) pour cette région. Avant le $20^{\mathrm{e}}$ siècle, la courbe SOR est raisonnablement cohérente, particulièrement à l'échelle décennale, avec une reconstitution indépendante de l'indice de sévérité de sécheresse de Palmer (ISSP) pour à peu près la même région. Une détérioration de la relation entre le climat et la croissance des arbres au cours des dernières décennies fait en sorte qu'un modèle de régression calibré avec des données récentes explique $21 \%$ de la variance dans les courbes originales pour le climat. Les auteurs ont par conséquent fait un compromis avec un modèle calibré sur la période de 1900 à 1960 qui explique $33 \%$ de la variance. Le modèle, bien qu'il ne soit pas très robuste, satisfait les tests de vérification indiquant qu'il a un certain degré de capacité de prédiction. La plus longue courbe dans notre réseau, la courbe de Flowerpot Island (FLOW) qui couvre 2787 ans, montre également une similitude avec la reconstitution de l'ISSP, particulièrement à l'échelle décennale et à plus grande échelle. Elle a été utilisée pour déduire les conditions hydro-climatiques jusqu'à 610 ans. L'information combinée des courbes SOR, ISSP et FLOW suggère qu'il y a eu des périodes sèches de 1700 à 1725 , de 1750 à 1800 et de 1840 à 1900 tandis que les périodes de 1675 à 1700,1730 à 1750 et 1810 à 1840 ont généralement été humides. Sur des échelles de temps plus longues, la courbe FLOW montre que les précipitations estivales ont été particulièrement variables au cours des $7^{\mathrm{e}}, 9^{\mathrm{e}}, 13^{\mathrm{e}}$ et $16^{\mathrm{e}}$ siècles.

[Traduit par la Rédaction]

\section{Introduction}

Long records of climate are necessary for assessing current global climate changes within the context of long-term variability. One important role of the paleoclimate community is to extend the instrumental record through the development of proxy records from natural archives such as tree rings, ice cores, corals, and sediments from terrestrial and marine sources. High-resolution time series in excess of 500 years are rare, even for the relatively data-rich areas of North America and Europe. Therefore, any such records have immediate value, particularly when they are shown to have a sensitivity to climate and can be used for studying past environmental changes. Tree-ring time series are particularly

Received 8 April 2004. Accepted 23 July 2004. Published on the NRC Research Press Web site at http://cjfr.nrc.ca on 25 December 2004.

B.M. Buckley ${ }^{1}$ and E.R. Cook. Tree-Ring Laboratory, Lamont-Doherty Earth Observatory, Palisades, NY 10964, USA.

R.J.S. Wilson. School of Geosciences, Grant Institute, The University of Edinburgh, Edinburgh EH9 3JW, UK.

P.E. Kelly and D.W. Larson. Cliff Ecology Group, Department of Botany, University of Guelph, ON N1G 2W1, Canada.

${ }^{1}$ Corresponding author (e-mail: bmb@ldeo.columbia.edu). 
Fig. 1. Location map of cedar sites, climate stations, the relevant $5^{\circ} \times 5^{\circ}$ grid for precipitation (1900-1994) and temperature (1864-1997), and Cook et al.'s (1999) Palmer drought severity index (PDSI) (Grid 133, 1680-1980) reconstruction. BP, Bruce Peninsula; DP, Door Peninsula. The Woodstock (1870-1988) and Toronto (1846-1990) precipitation records were taken from the Historical Canadian Climate Data network and have been corrected for homogeneity problems (Mekis and Hogg 1999).

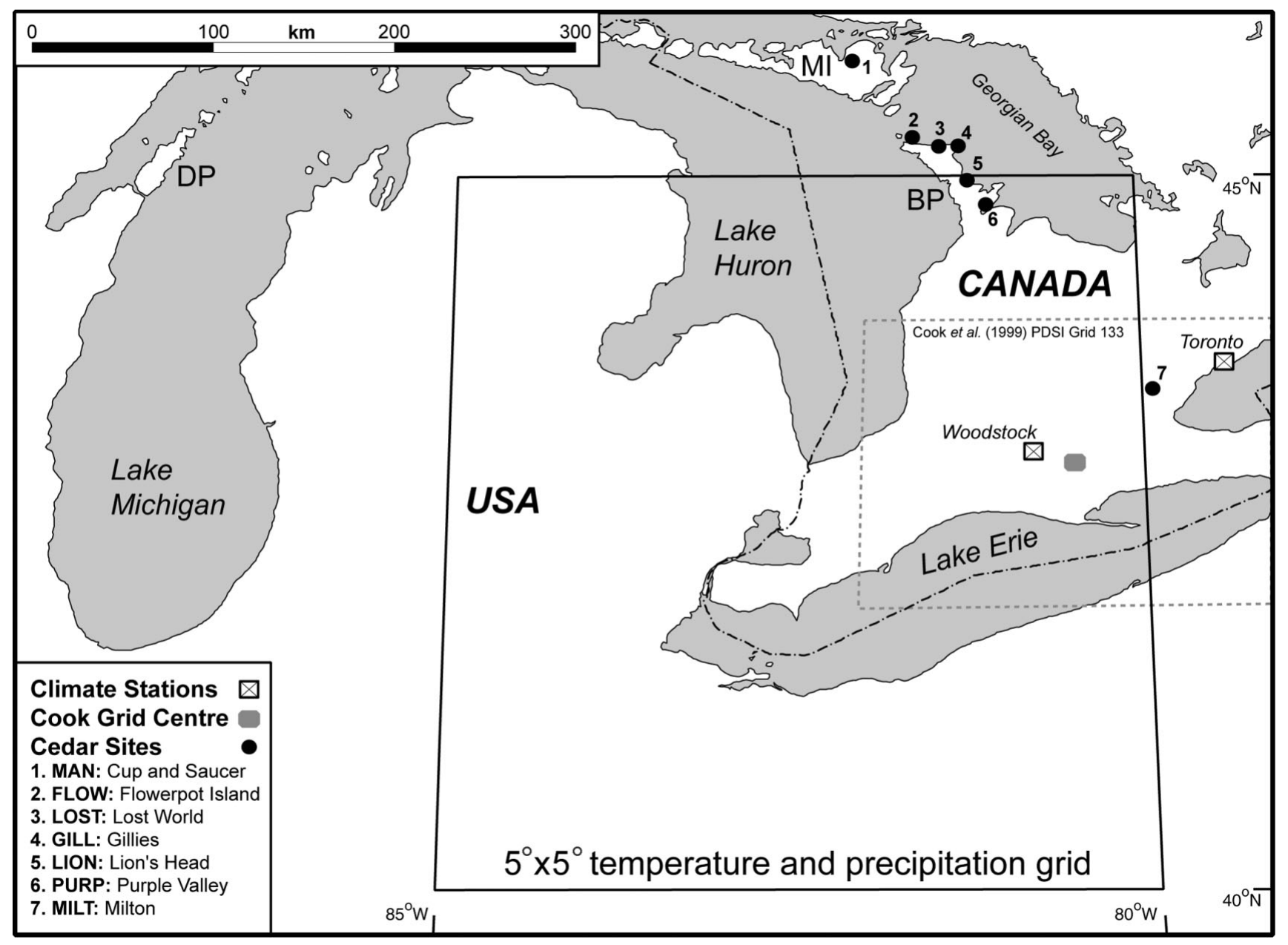

relevant to recent climate studies because of their annual resolution and, when standardized carefully, their ability to retain low-frequency variance on time scales of decades to centuries (e.g., Esper et al. 2002).

Eastern white-cedar (Thuja occidentalis L.), found growing on the cliffs of the Niagara Escarpment, form one of the oldest-known living forest systems in eastern North America (Larson and Kelly 1991; Kelly et al. 1992, 1994; Larson et al. 2000). Kelly et al. (1994) developed a 1397-year ringwidth chronology from living and preserved dead cedar trees of the northern Bruce Peninsula (Fig. 1), from which they detailed the potential of this species for developing long dendroclimatic reconstructions. Their research indicated a significant response to temperature (negative) and precipitation (positive) in July of the year prior to growth. This same response signature was seen weakly in the current year of growth as well, though the timing was slightly different and the results not statistically significant.

Archambault and Bergeron (1992), Tardif and Stevenson (2001), and Tardif and Stevenson (1997) also used T. occidentalis for dendroclimatic research and demonstrated a significant response to precipitation and drought in each of these instances in their studies of trees from Quebec and Mani- toba, respectively. For all these studies on T. occidentalis, the response to climate incorporated negative response to temperature with positive response to early summer rainfall, with the latter response being least pronounced in the Niagara Escarpment cedar. The difference in site characteristics between these locations can account for much of this variable tree response. For example, the Quebec and Manitoba sites were not from cliff-face trees and were much farther north, where temperature is more limiting to growth (Tardif and Stevenson 2001). In spite of this temperature limitation, however, the trees demonstrated consistent response to moisture availability during the growing season, particularly in conjunction with warm temperatures. In this paper, we argue for a moisture response in the Niagara Escarpment cedar trees, similar to what these other studies found.

The cedars of the Niagara Escarpment are an important resource to the paleo community because of their great age combined with their proximity to one of the most densely populated and heavily industrialized regions of North America, an area that plays a significant role in the release of the aerosol gases that are central to the global warming debate. In addition, the Great Lakes constitute the largest volume of fresh surface water on earth, containing roughly $18 \%$ of the 
Table 1. The seven cedar chronologies from southern Ontario and Manitoulin Island (Fig. 1), with the number of radii and time span.

\begin{tabular}{lcc}
\hline Site & No. radii & Chronology length \\
\hline MAN & 63 & $1495-1999$ \\
FLOW & 169 & $-798-1989$ \\
LOST & 38 & $1381-1998$ \\
GILL & 88 & $1399-2001$ \\
LION & 127 & $863-2000$ \\
PURP & 52 & $1601-1989$ \\
MILT & 180 & $1379-1991$ \\
\hline
\end{tabular}

Note: MAN, Manitoulin; FLOW, Flowerpot Island; LOST, Lost World; GILL, Gillies; LION, Lion's Head; PURP, Purple Valley; MILT, Milton.

world supply (Environment Canada and US Environmental Protection Agency 1995). Large changes in the region's water storage, resulting from changing climate conditions, would have consequences for millions of people living in the region, with potentially global repercussions of an economic and ecological nature. The ability to explore the long-term natural variability of past environmental changes, including climate, from long proxy records is of enormous value in assessing currently changing trends, and the Niagara Escarpment cedars afford such an opportunity.

In this paper, we present previously unpublished chronologies of living cedar from along the Niagara Escarpment, and an extended version of the Kelly et al. (1992, 1994) Flowerpot Island chronology (henceforth referred to as FLOW). This chronology is now 2787 years long and is currently the longest tree-ring record from eastern North America and one of the longest in all of North America. We use the entire chronology network to develop a 350-year JuneJuly precipitation reconstruction for the region that explains $33 \%$ of the variance in the original climate series. We then infer hydroclimatic conditions for the past 1400 years, based on the long FLOW chronology, and compare this with other proxy records for the region. While the 33\% explained variance of our reconstruction may be considered somewhat weak in terms of predictive skill, it may still be of great interest to policy-makers in the Great Lakes region who wish to place recent and projected changes in climate within the context of the long-term natural variability of climate for the region.

\section{Materials and methods}

\section{The chronology network and the study region}

The seven chronologies presented in this paper come from T. occidentalis trees growing on cliff locations along the Niagara Escarpment (Table 1). Site locations range from Manitoulin Island, across the northern tip of the Bruce Peninsula, to the cliffs just southwest of Toronto (Fig. 1). This tree species occurs abundantly in both wetland and rocky upland areas of northeastern North America, but several genetic studies have shown that the species broadly interbreeds and is genetically homogeneous throughout this range (Matthes-Sears et al. 1991; Matthes-Sears and Larson 1991). Multiple genotypes of several enzymes have been found in the central and south- ern portions of the range of this species (Walker 1987), but functionally distinctive ecotypes have not been found.

The exposed Niagara Escarpment is primarily composed of limestone and dolostone and in the study area forms a ridge of gently tilted rock strata, with a long, gradual dip slope to the west and a steep escarpment or cliff to the east. Cedar trees growing on these cliff faces are prone to root mass restriction, but are only marginally limited by nutrient or water supply (Matthes-Sears et al. 1995). It is only during periods of severe drought and high temperature that these trees have the potential to be moisture stressed. It is therefore likely that microsite conditions, even to the individual tree level, may be exerting substantial influence on the sampled trees in many instances.

The climate of the Niagara Escarpment in southern Ontario is strongly influenced by its proximity to the Great Lakes. Temperature and precipitation both exhibit pronounced seasonal variability, reflecting the temperate latitude of the region. Average maximum temperature in the warmest month is $29.9{ }^{\circ} \mathrm{C}$, while the average minimum temperature in the coldest month is $-7.1^{\circ} \mathrm{C}$. The mean annual total precipitation is around $818.5 \mathrm{~mm}$, although there is great spatial variability with distance from the lakes and proximity to "snow-belt" zones that lie mostly south of the Bruce Peninsula (Environment Canada and US Environmental Protection Agency 1995). Additionally, the changing aspect of cliff faces and exposure to air that is tempered by the massive body of Lake Huron create microclimate conditions that can be quite locally variable.

\section{Climate data}

Precipitation (Hulme 1992, 1994; Hulme et al. 1998) and temperature (Jones 1994; Parker et al. 1995; Nicholls et al. 1995) data were obtained for a $5^{\circ} \times 5^{\circ}$ grid that encompasses much of the study region (Fig. 1). Despite the large spatial coverage of this grid, experimentation (analyses not shown) with local station data and neighbouring grids showed that these data were the optimal climate data sets for correlation function analysis. However, to aid verification of the precipitation reconstruction detailed later, the gridded precipitation data were extended using data from Toronto and Woodstock (Fig. 1). These two records were first normalized to their respective common period and averaged. The mean and standard deviation of this two-station mean series were adjusted to that of the gridded precipitation data over the period 1900-1990, and the data from the period 1846-1899 were used to extend the gridded data. This analysis was undertaken separately for each month.

\section{Chronology development}

The seven cedar chronologies are plotted in Fig. 2, along with sample depth and a measure of signal strength through time. For all samples we used standard procedures as outlined in Stokes and Smiley (1968) and Fritts (1976) with regard to field collection, sample preparation, dating control (i.e., cross-dating), and measuring procedures. The tree-ring samples for this project were obtained from two general situations. The first involved the extraction of core samples from living trees growing on vertical cliff faces or on the talus below the cliffs. The second source of samples came from cross-sections or core samples taken from dead stems, either found in situ, still rooted on the cliff faces or talus, or as 
Fig. 2. The seven cedar ARSTAN chronologies from Manitoulin Island and the Bruce Peninsula. The expressed population signal statistic (EPS; Wigley et al. 1984) and sample depth through time are shown in the upper and lower sections of each graph respectively. The chronologies are smoothed with a 25-year spline. MAN, Manitoulin; FLOW, Flowerpot Island; LOST, Lost World; GILL, Gillies; LION, Lion's Head; PURP, Purple Valley; MILT, Milton.
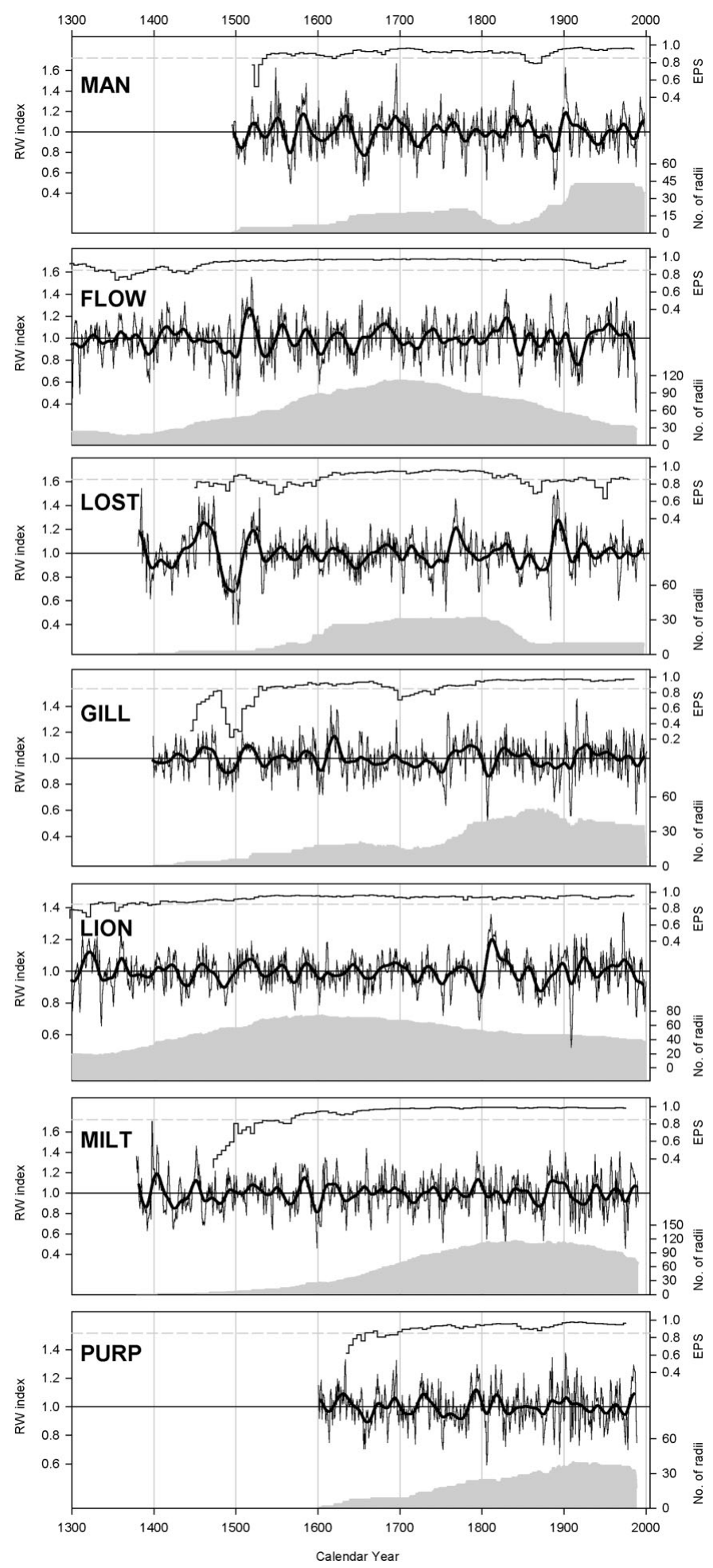

fallen $\operatorname{logs}$ at the base of the cliffs or on ledges. All core samples were obtained with standard $5 \mathrm{~mm}$ diameter increment corers that cause minimal damage to living trees. Handsaws were used to obtain cross-sections from dead trees where necessary.

For the development of the indexed chronology, a twostep standardization procedure was employed to reduce the potential biasing effects of traditional methods, while preserving multidecadal frequency variation related to climate. First, the variance of each series was stabilized prior to standardization, using a data-adaptive power transformation based on the local mean and standard deviation, as described by Cook and Peters (1997). Second, a fixed 150-year spline (with a $50 \%$ frequency-response cut-off) was fitted to each raw series, and this trend was then removed by subtraction. We used residuals rather than ratios during the standardization process to avoid the potential biasing effects that can result from using division, as demonstrated by Eriksson (1989) and, more fully, by Cook and Peters (1997), who clearly describe the potential for overestimation of the recent decades in tree-ring chronologies with the use of the ratio method. Autoregressive modeling was then applied to each tree-ring series (Cook 1985), and the biweight robust mean was calculated to reduce the influence of outliers in the computation of the mean chronologies. Finally, the variance of the chronologies was temporally stabilized using techniques outlined in Osborn et al. (1997) to reduce the effects of changing sample size. This process removes a potential bias of changing variance that is not climatically driven. It should be noted that the use of the fixed 150-year spline results in a chronology that captures multidecadal to higher frequencies. All potential centennial-scale variability has to be removed from these data.

The temporal sample depth of each chronology is shown in Fig. 2, along with the Expressed Population Signal (EPS) statistic as outlined by Wigley et al. (1984). The EPS statistic shows the strength of a chronology signal through time. While there is no level of significance for EPS per se, values above 0.85 are generally accepted in dendrochronology as showing an acceptable level of common signal fidelity. Periods of the record that dip below this accepted threshold level should be viewed more critically when one is trying to make inferences about climate or other environmental factors that are derived from the tree-ring time series.

\section{Correlation matrix and principal component analysis}

Intersite comparison was assessed using correlation matrix and principal component analysis (PCA) over the 16501989 period, where the signal strength of the chronologies is acceptable based on the EPS criteria, as noted previously (Fig. 2). PCA, as used in this study, involves the extraction of orthogonal (uncorrelated) principal components, or factors, from an original set of correlated variables by employing a variance maximizing ("varimax") rotation of the original variable space (Richman 1986). In a scatterplot, for example, we can think of the regression line as the original $x$-axis, rotated so that it approximates the regression line. This type of rotation is called "variance maximizing", because the criterion for, and goal of, the rotation is to maximize the variance of a new set of uncorrelated variables (factors) while 
Table 2. Correlation matrix of the seven ARSTAN chronologies for the common period 1650-1989.

\begin{tabular}{|c|c|c|c|c|c|c|c|}
\hline Site & MAN & $\begin{array}{l}\text { FLO } \\
\mathrm{W} \\
\end{array}$ & LOST & GILL & LION & PURP & MILT \\
\hline MAN & 1 & 0.41 & 0.23 & 0.45 & 0.46 & 0.38 & 0.31 \\
\hline FLOW & & 1 & 0.39 & 0.46 & 0.55 & 0.23 & 0.19 \\
\hline LOST & & & 1 & 0.29 & 0.40 & $0.07 *$ & $0.05 *$ \\
\hline GILL & & & & 1 & 0.49 & 0.44 & 0.34 \\
\hline LION & & & & & 1 & 0.32 & 0.20 \\
\hline PURP & & & & & & 1 & 0.74 \\
\hline MILT & & & & & & & 1 \\
\hline Mean $\mathrm{r}$ & 0.37 & 0.37 & 0.24 & 0.41 & 0.40 & 0.36 & 0.30 \\
\hline
\end{tabular}

Note: MAN, Manitoulin; FLOW, Flowerpot Island; LOST, Lost World; GILL, Gillies; LION, Lion's Head; PURP, Purple Valley; MILT, Milton.

*Correlations not significant at the $95 \%$ confidence limit.

Fig. 3. (a) Loadings of the first two variance maximizing (varimax) eigenvectors (eigenvalues $>1.0$ ) for the cedar chronology network. (Note: LOST was not included in this analysis because of weak signal strength). (b) Time-series plots of the two significant principal components (PC1 and PC2). The heavy line is a 25-year cubic smoothing spline.

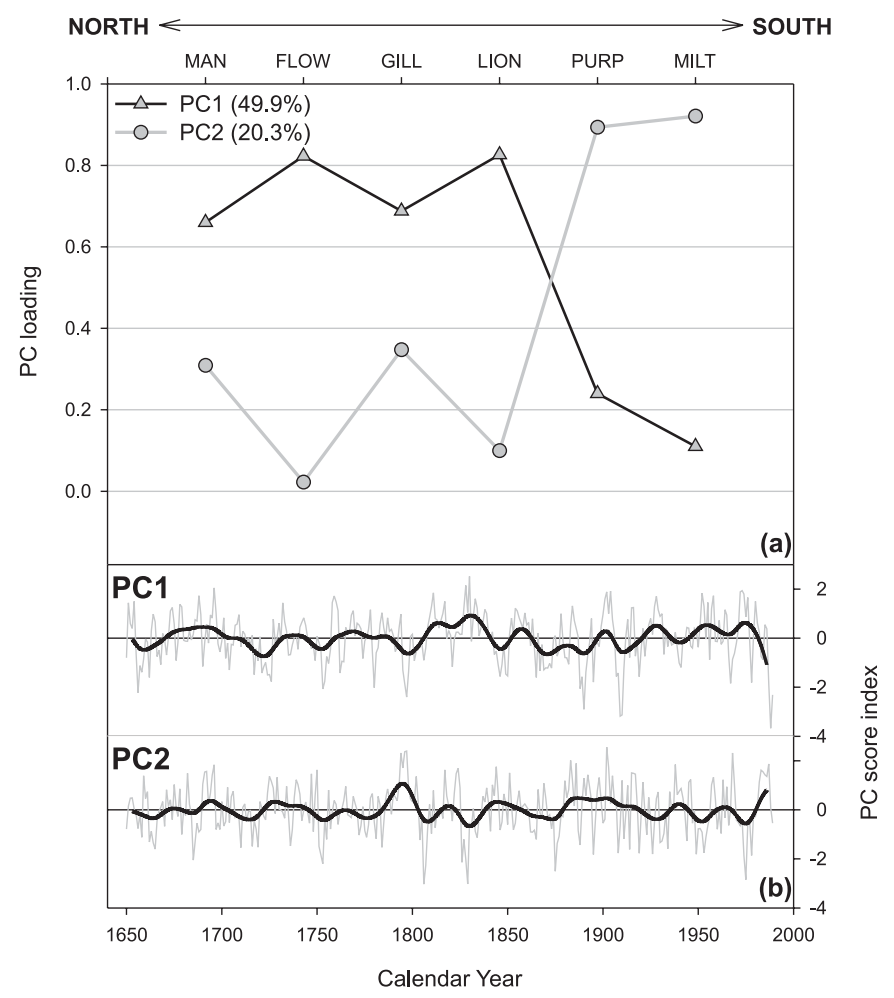

minimizing the variance around these new variables. Factor analytic techniques are employed to reduce the number of variables and to detect structure in the relationships between variables. Therefore, PCA is applied as a data reduction or structure detection method and is widely used in dendroclimatology (Briffa 1995). We employed this technique in this study to assess the common variance modes of tree-ring variability between all sites over a common period spanning 1650-1989. The varimax rotation was used to aid the interpretation of the individual site loadings on each eigenvector.
(For a full description and justification of the rotation procedure, see Richman 1986.)

\section{Climate response analysis}

Correlation function analyses were performed between the identified principal component scores from the cedar network and monthly variables of the gridded precipitation and temperature data. The results are similar to those using the individual chronologies. However, because of the noisier nature of comparing correlation functions from individual sites, we present here only the correlations from the principal components, as they express the dominant modes of variance in the data and will be used to develop a regional reconstruction of climate. Therefore, it should be noted that while the varimax factor scores are based on the original tree-ring time series and are not entirely independent, they are orthogonalized variables and are not constrained to respond in a similar fashion to the original variables. We interpret the similarity between the single site and principal component correlation functions as further validation of the response functions themselves.

\section{Results and discussion}

The living data of the MAN, LOST, and GILL sites are entirely represented by talus trees, differing markedly from the FLOW, LION, PURP, and MILT sites, which are dominated by trees that were growing on vertical surfaces, away from disturbances such as fire. The correlation matrix in Table 2 illustrates the extent of regional agreement between the chronologies. The seven chronologies are not so strongly correlated, except for the PURP and MILT, which correlate at 0.74 . The LOST chronology is the most weakly correlated series in the network and also shows weak signal strength in the 19th and 20th centuries. In addition to relatively low replication (Fig. 2), there is evidence of fire-related disturbance at this site that probably exacerbates its weaker signal strength through this period. Some of the standing dead trees at this site had an outer date of 1884 and showed signs of charcoal. There was also a sharp growth release in the surviving trees subsequent to this apparent fire event. It resulted in a period of high index values in the LOST chronology at the end of the 19th century (Fig. 2). Therefore, because of low replication in the living portion and the known fire- 
related disturbance, we removed this chronology from all ensuing analyses.

The PCA identifies two eigenvectors that have eigenvalues greater than unity, the loadings and scores of which are shown in Fig. 3. These two factors define a general northsouth split between the chronologies, with the PURP and MILT chronologies dominating the second principal components (PC2) and the northern chronologies (MAN, FLOW, GILL, and LION) dominating the first (PC1). It is interesting to note that both the correlation matrix analysis (Table 2) and the PCA (Fig. 3a) indicate that the PURP chronology exhibits strongest agreement with the MILT chronology, despite a substantial distance and its more proximal location to the LION chronology (Fig. 1). It is not clear to us why the PURP and MILT data are so highly correlated, but their strong common signal implies that the two sites express similar ecological characteristics or that a large-scale regional forcing (presumably climate) is influencing growth in a similar fashion at both of these locations, but not elsewhere throughout the study location. The relatively low intersite correlations (Table 2) of the other chronologies imply that site-specific factors, possibly related to microclimate or local hydrological conditions, may play a more significant role in modulating the response of cedar trees to this potential common forcing. Work is currently in progress to collect new tree-ring series from ancient trees at multiple locations along the Niagara Escarpment. Once analyzed, these data may allow a resolution of the causes of the site-specific differences found here.

\section{Climate response of $T$. occidentalis}

The response of the chronologies and their respective principal components is complex and appears to be unstable through time. Over the 1900-1960 period, PC2 (i.e., PURP and MILT) shows the strongest relationship with climate, expressed as a positive relationship with June-July precipitation of the current year and June and August of the previous year (Fig. 4a). These observations are coupled with a negative correlation with January and June temperatures and positive correlations with March and April temperatures. While these correlations do find significance at the $95 \%$ level of confidence, we would like to emphasize that not only are they relatively weak, but they also change for the later 1961-1989 period. For this latter period, no significant correlations with precipitation are identified, although a similar response to temperature is noted, with negative correlations with January and a positive correlation with April.

In general, the correlations of PC1 (i.e., the northern chronologies) with climate variables are much weaker than those for PC2 and are likewise variable through time. For the early period, significant correlations $(p<0.05)$ are found with current July (positive) and February (negative) precipitation and with previous August (negative) temperatures, while for the later period significant correlations are found with March (positive) precipitation and present June-July (negative) and previous July (negative) temperatures.

The climate correlation analyses detailed by Kelly et al. (1994) of the original FLOW chronology are similar to those of PC1, showing a significant $(p<0.05)$, inverse response to temperature in the prior growing season, in conjunction with a (weakly) significant, direct response to precipitation. Tardif and Stevenson (2001) reported similar response functions to PC2 for the 1900-1961 period for white-cedar from Manitoba, exemplified by a positive correlation with June-July precipitation, coupled with a negative correlation with June temperature. Negative correlations were also found between growth and prior-year August maximum temperature, suggesting that water stress could lower the accumulation of the trees' carbohydrate reserves and result in growth reduction the following year (Tardif and Stevenson 2001). Archambault and Bergeron (1992) found a very similar response for white-cedar in Quebec, as did Kelly at al. (1994) for the Niagara Escarpment and as we now have in the current paper.

The results of Kelly et al. (1994) and those presented for PC1 (Fig. 4) imply that cool and wet conditions during the growing season serve to "precondition" the trees for positive growth the following season. Conversely, dry and hot conditions adversely affect the following-year's growth, resulting in a narrow growth ring. We interpret this as a sensitivity to moisture availability, since maximum temperature on the cliff face increases during dry, cloudless summer months and might be expected to cause heat stress, stomatal closure, a decrease in water use efficiency, and, consequently, a reduction of radial growth (e.g., Fichtner et al. 1994).

It should be noted that $T$. occidentalis is an indeterminate growth species, meaning that one year's foliar growth is not determined by the setting of buds from the prior season. This is important when assessing the climate-growth model results, because it implies a direct input-output relationship between growth and environmental factors such as climate. Matthes-Sears et al. (1995) supplied a nutrient-rich solution to cliff-dwelling, white-cedar saplings along the Niagara Escarpment in southern Ontario and noted a significant increase in several measures of productivity directly following treatments, a finding that supports the aforementioned hypothesis. For example, the diurnal carbon uptake was altered, and shoot elongation and leaf area growth were both enhanced. Annual radial growth, however, in the form of measured ring width, did not experience a related increase until the following growing season. This is attributed to the fact that stem growth has the longest response time and only occurs once the resource demands of foliage and root growth have been met (Waring 1987). Furthermore, field observations of $T$. occidentalis over several seasons, both on the Bruce Peninsula (U. Matthes-Seares, unpublished data) and the Door Peninsula in Wisconsin (B.M. Buckley, unpublished data), show that cell division for ring growth in $T$. occidentalis may already be taking place as early as March and may be completed for the season as early as late June. This may help to explain the climate correlation analyses of Kelly et al. (1994), suggesting that the prior-season's climate sets the conditions for radial growth in the following year. It should be noted, however, that Ahlgren (1957) and Forster et al. (2000) report that radial growth for $T$. occidentalis is actively taking place from mid-May to mid-August.

The positive correlations of PC2 with present-year JuneJuly precipitation also imply a dominant summer hydrological control on growth. Archambault and Bergeron (1992) found that drought during the season of growth was the limiting factor for their 802-year T. occidentalis chronology 
Fig. 4. Correlation functions for principal components PC1 and PC2 against monthly time series of $(a)$ precipitation- and $(b)$ temperaturegridded climate data. Analysis was made over two periods: 1900-1960 and 1961-1989. Highlighted bars denote correlations significant at the $95 \%$ confidence limit.

(a)

\section{CORRELATIONS WITH PRECIPITATION}

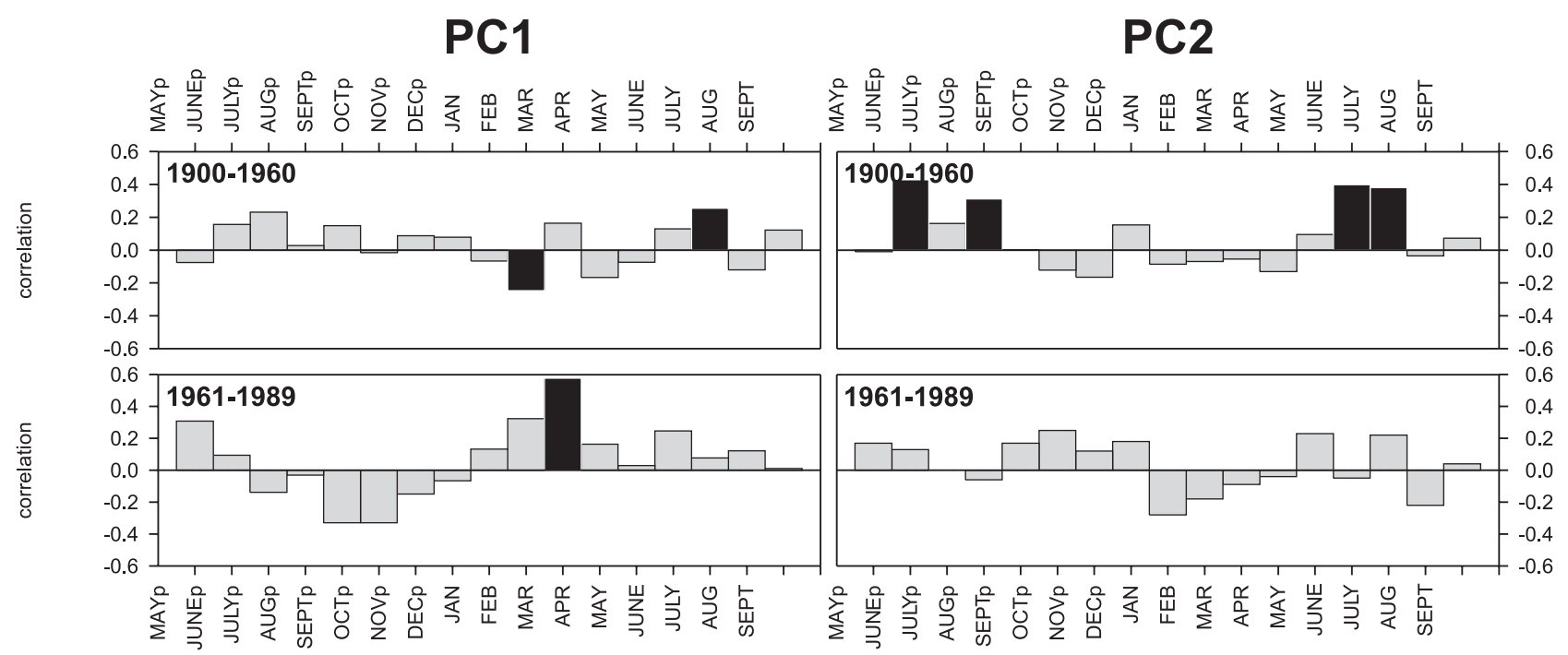

(b) CORRELATIONS WITH TEMPERATURE

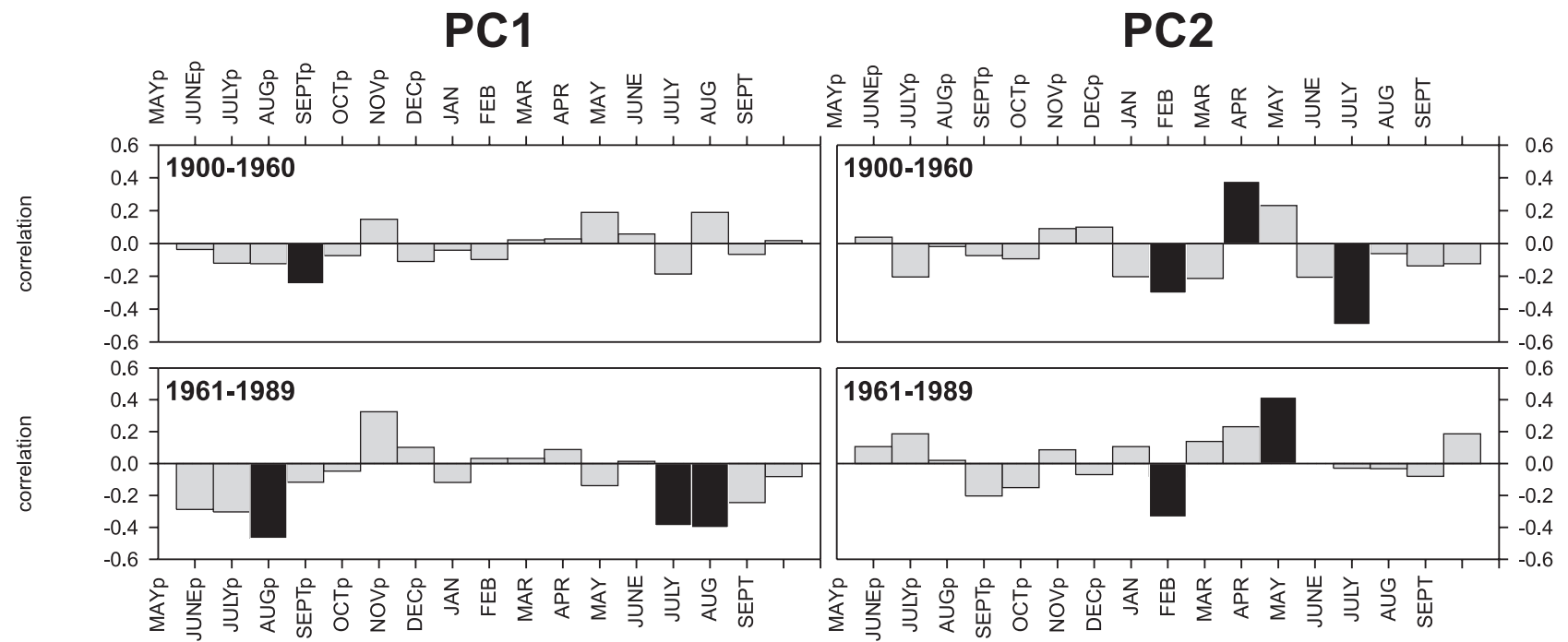

from western Quebec (manifested as a positive correlation with June precipitation and a negative response to temperature in the same month). Given the previous discussion on the response of radial growth of $T$. occidentalis to previousand current-year's climate, we hypothesize that our Thuja chronologies are, in general, sensitive to localized hydro meteorological conditions and can be used to analyze past moisture and drought conditions for the region, within the limitations of the climate calibration as presented in this paper. The weakening of the response to precipitation in the late 20 th century is discussed in the following section.
Dendroclimatic reconstruction of June-July precipitation

The climate - tree growth correlation analyses demonstrate relationships with present- and previous-year's climate (Fig. 4). Therefore, the PC scores with eigenvalues $>1.0$ (Fig. $3 b$ ), lagged at $t$ and $t+1$, were used as potential predictors for the reconstruction of climate. Using a stepwise multiple linear regression $(F$ to enter $=0.01 ; F$ to remove $=0.05)$, we made calibration trials over the 1900-1988 period (represented by the gridded data) against a variety of seasonalized climatic parameters of precipitation and temperature. Considering both calibration and verification statistics, we determined 
Fig. 5. Regression model calibration and verification. (a) Comparison between actual and reconstructed June-July precipitation totals. The reconstructed values have been scaled to the mean and variance of the actual data. Calibration and verification statistics and the regression equations are also shown. Verification 1, 1846-1899; verification 2, 1961-1988; *, verification significant at the 95\% confidence limit. The reduction of error (RE) is a measure of the common variance between the actual series and the tree-ring estimates, for which a positive value indicates skill in the regression (Cook et al. 1994). The sign test (ST), which measures how well the reconstructed estimates track the year-to-year variations in the instrumental data (Fritts 1976; Cook and Kairiukstis 1990). (b) Sliding 31year window correlations between the actual and reconstructed precipitation values. $(c)$ Comparison between low-pass filtered versions (10-year spline) of the actual and reconstructed precipitation data. The smoothed series were normalized to $z$-scores over their common period. Because of the loss in degrees of freedom of smoothing the data, the correlations are not significant at the $95 \%$ confidence limit. However, they provide a guide to the common variance at decadal time scales between the series.

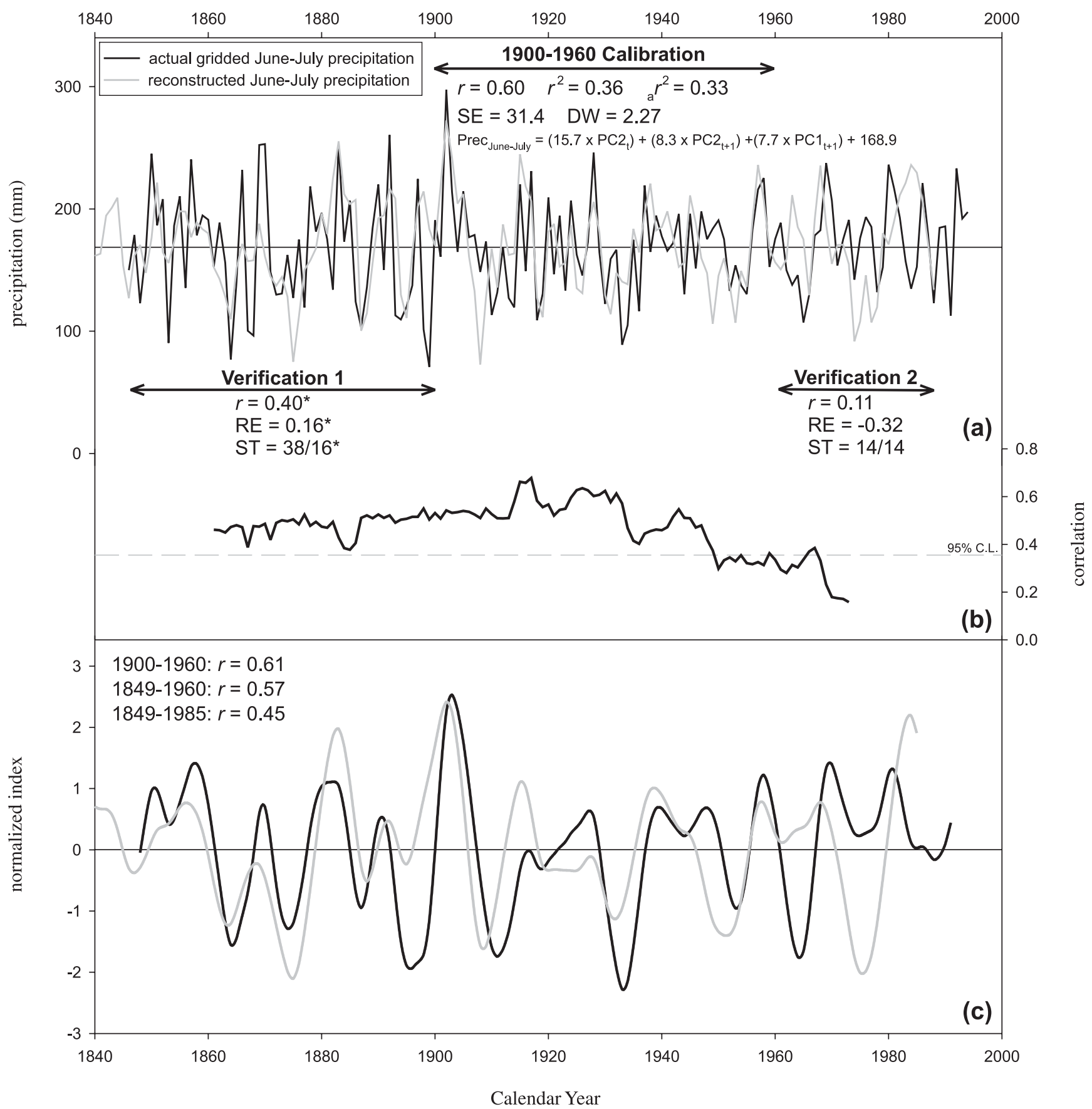

that the optimal season for reconstruction was June-July precipitation. This final full period model explains $21 \%$ of the variance in the original precipitation data. We admit that this value is low, but the poor results are exacerbated by a distinct weakening in the relationship between actual and modeled precipitation values through the 20th century.

Calibration over the 1900-1960 period substantially improves the results, with $33 \%$ of the precipitation variance be- 
ing accounted for (Fig. 5a). The model verifies well over the 1846-1899 period $(r=0.40$; RE (reduction of error) $=0.16$; ST $($ sign test $)=38 / 16)$, but fails verification over the 19611988 period $(r=0.11 ; \mathrm{RE}=-0.32 ; \mathrm{ST}=14 / 14)$, highlighting the weakening in signal in the tree growth - climate relationship for recent decades. This weakening is clearly shown in Fig. $5 b$ by the running 31-year correlation between the actual and modeled precipitation data. That shows relatively stable correlations with June-July precipitation from 1846 to the mid 20th century, followed by a significant weakening of the calibration statistics after this period. Comparison of decadally-smoothed versions of the actual and modeled precipitation values (Fig. 5c) also shows that there is reasonably stronger fidelity of the model at decadal scales from the 19th to mid-20th centuries.

Traditionally, in dendroclimatology, a split-period calibrationverification exercise would be employed to assess the temporal fidelity of a modeled signal (Fritts 1976). In Fig. 5a, we only present the calibration results for the 1900-1960 period, because it portrays the strongest calibration results when modeling June-July precipitation. If the post-1960 period is ignored, calibration on the 1846-1899 period explains only $14 \%$ of the variance, but verifies well for the 1900-1960 period ( $r=$ $0.55 ; \mathrm{RE}=0.28 ; \mathrm{ST}=42 / 19$ ). Although it could be argued that the signal fidelity in the ring width data in the 19th century is weaker, it is also likely that the signal strength of the precipitation data themselves is weaker. Those data are only represented by data from one or two stations (Woodstock and Toronto), whereas the 1900-1960 period in the gridded data will have been generated from more station data. For this reason, the final reconstruction presented hereafter in this paper is that generated from the 1900-1960 calibration.

We should note that we are currently unable to derive a satisfactory explanation for the loss of fidelity in the growthclimate model in recent decades (Figs. $5 b$ and $5 e$ ). Several dendroclimatic studies from various northern hemisphere locations have also noted a weakening in the growth-climate response since the 1950s (e.g., Jacoby and D'Arrigo 1995; Briffa et al. 1998a, 1998b; Vaganov et al. 1999; Barber et al. 2000; Brázdil et al. 2002; Lloyd and Fastie 2002; Wilson and Luckman 2003; Wilson and Elling 2004). However, as a variety of factors have been proposed to explain this weakening in growth-climate response, the reasons are likely regionally specific. In the case of the Niagara Escarpment cedar, the fact that PC2 (more heavily weighted in the regression model) is derived from two widely spaced sites suggests that whatever mechanism is affecting the tree's response to climate, it is not likely to be site specific. Also, the fact that PC2 shows consistent correlations with January (negative) and March-April (positive) temperatures through the 20th century (Fig. 4b) indicates that temperature is likely an important factor in tree productivity and may modulate the response of this species to precipitation.

The previous section detailed the development of a JuneJuly precipitation reconstruction for southern Ontario (henceforth referred to as SOR). Although the regression model explains only $33 \%$ of the precipitation variance over the 1900-1960 calibration period (Fig. 5a), the reconstruction does portray predictive skill when verified over the 18461899 period. The SOR (Fig. 6a) indicates dry conditions over the periods $1655-1670,1705-1725,1745-1760$, around
1775 and 1805 , and during the period 1860-1880. The 20th century appears fairly unremarkable, with generally average conditions throughout.

When compared with an independent tree-ring-based PDSI reconstruction (Cook et al. 1999; henceforth referred to as COOK) for a $2^{\circ} \times 3^{\circ}$ grid square centered over southern Ontario (Fig. 1), the correlation between the reconstructions is -0.07 and 0.31 , respectively, over the periods $1680-1845$ and 18461960 (Fig. 6). As both series reconstruct the summer season and portray a similar region, this weak covariance is surprising, especially since the correlation between June-July precipitation and June-July PDSI for this region is 0.60 over the 1900-1960 period.

The FLOW chronology (Fig. 6c), which was included in the original PCA data matrix (Fig. 3), appears to show decadal characteristics similar to both SOR and COOK. For example, from 1650 to 1780 , FLOW qualitatively shows similar variability to SOR, while in the 19th century it more closely resembles COOK. However, the correlations between these chronologies over the 1680-1845 and 1846-1960 periods show the opposite, with the strongest coherence being noted between FLOW and COOK for the early period $(r=$ 0.26 ) and a correlation of $r=0.27$ between FLOW and SOR for the later period.

The period of greatest difference between all three series in Fig. 6 is in the late 20th century, which reiterates the problems noted earlier for calibration. The number of extreme (>1.5 SD away from the 1900-1960 reference period) negative and positive years in each series in Fig. 6 is generally higher in the 20th century. This increased variability could be interpreted as being related to a more variable climate, but could also result from disturbance in the last 100 years or so. Kelly et al. (1994) noted that the strong depression in growth in the FLOW chronology after 1908 (Fig. 6) cannot be explained by climatic variables, and instead might reflect a response to a fire that had swept over the Bruce Peninsula region in 1908. As the FLOW chronology is weighted strongly on $\mathrm{PC} 1$, this is one possible reason for the weak response of this chronology and its related PC to climate.

Brinkman (1987) reconstructed water supplies to the Great Lakes using tree-ring data (species included red pine, hemlock, white pine, pitch pine, and chestnut oak). His reconstructions show a tendency for above-average values during the first half of the 1800s and below-average values during the latter half. Similar trends are also seen in the three records presented in Fig. 6. In particular, wet summer conditions can be inferred from COOK and FLOW around the 1830s. High lake levels were recorded during this period, while regional climate records indicate that the 1830 s were wet over most of the Great Lakes region (Brinkman 1987). Therefore, by pooling the information of each record in Fig. 6, we can infer wet conditions prior to the 20th century over the periods $1675-1700,1730-1750$ and 1810-1840 and drier conditions for the periods $1700-1725,1750-1800$, and 18401900 .

After low-pass filtering (25-year splines; Fig. 6), the correlations between FLOW and both the SOR and COOK series over the 1683-1900 period are 0.13 and 0.57 , respectively. The reasonable coherence with the $\mathrm{COOK}$ record at decadal scales, although not significant at the $95 \%$ confidence limit because of the autocorrelation in the smoothed series (e.g., 
Fig. 6. Normalized (relative to the 1900-1960 period) time-series plots of (a) the southern Ontario precipitation reconstruction (SOR), (b) Grid 133 in Cook et al.'s (1999) Palmer drought severity index (PDSI) reconstruction for southern Ontario (COOK), and (c) the Flowerpot chronology (FLOW). The bold lines are 25-year cubic smoothing splines. The correlation matrices were calculated between the chronologies over the periods $1680-1845$ and 1846-1960. *, denotes significant (95\% confidence limit) correlations. For the unfiltered series, the number of extreme (>1.5 SD) annual values above and below the 1900-1960 reference period are shown for each complete 50-year period.

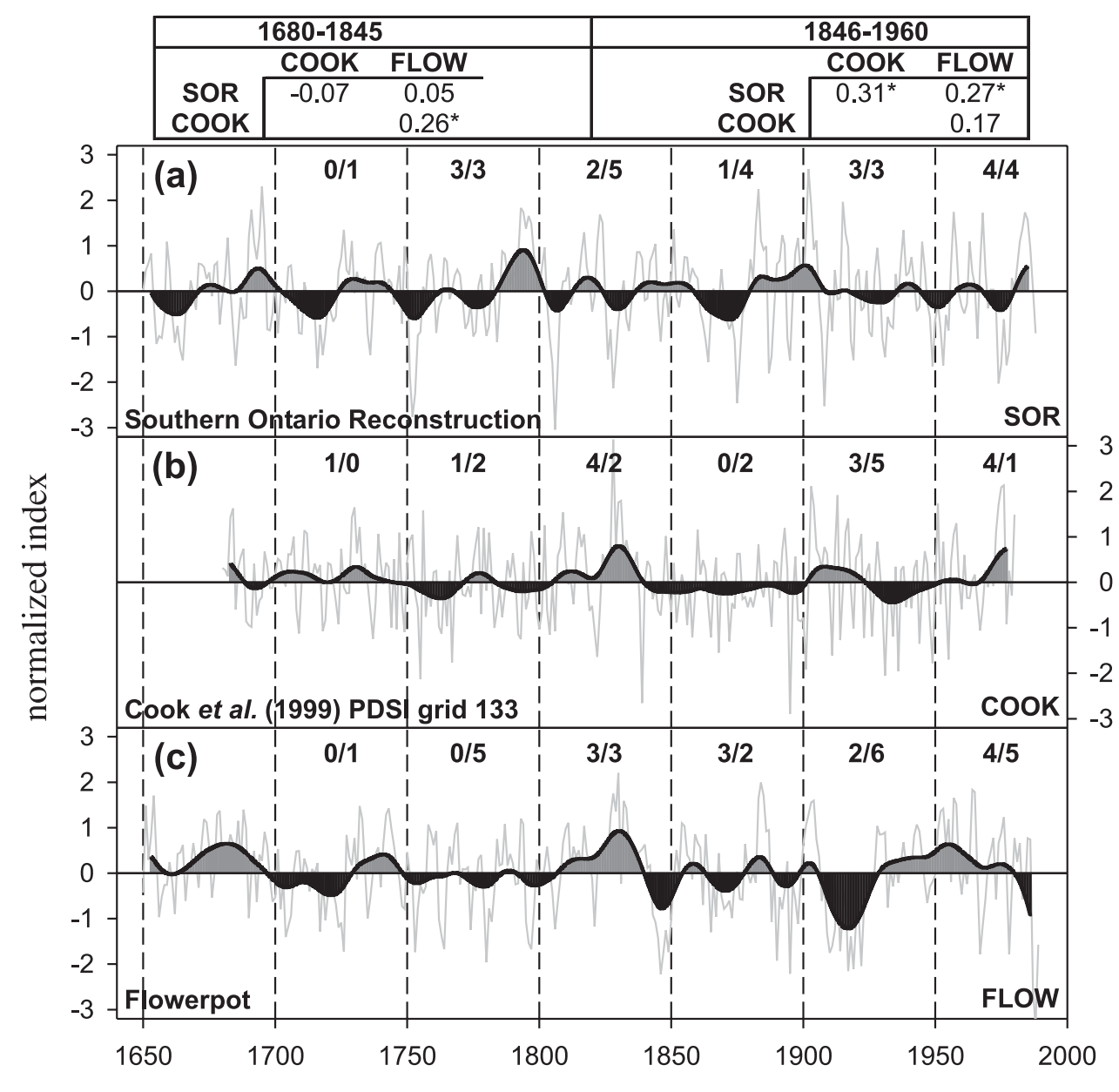

Calendar Year

Trenberth 1984), supports our contention that the FLOW chronology alone provides important information about past moisture availability at multidecadal scales. It is surprising, however, that the correlations between FLOW and SOR are not higher, as these series are not entirely independent because FLOW is included in the SOR model as a significantly weighted variable on PC1.

Figure 7 presents the FLOW chronology back to AD 610, the period during which the EPS value of the chronology is greater than 0.85 (Wigley et al. 1984). Given that we are interpreting FLOW as a proxy of summer precipitation, we can identify multidecadal periods of above- or below- average growth (precipitation) over the last 1400 years. By calculating 10-year averages of the normalized data, we have been able to identify extreme nonoverlapping decadal periods in the record. Excluding the 20th century, where the cedar chronology shows depressed growth in the early 20th century because of fire effects, 15 dry and 9 wet extreme decadal periods have been identified over the period 610-1899 (Fig. 7; Table 3).

The driest decade, 1234-1243 (Table 3), was soon followed by the second wettest decade (1268-1277). This relatively rapid change in hydroclimatic conditions is not unique in the FLOW record. For example, the most prolonged dry period, from ca. 800-840 (which includes the decadal extremes 803-812 and 822-831), was preceded and followed by relatively wet conditions. There are three distinct "drywet-dry" periods: ca. 650-700, ca. 1000-1060, and ca. 14801540. In general, the 16th century portrays extremely variable hydroclimatic conditions. Dry conditions were prevalent at the end of the 15th century (1496-1505, the fourth driest decade), followed by the wettest decadal period (1512-1521) and then a second dry period (1530-1539). Stahle et al. (2000) highlighted the 16th century as a period of extreme hydroclimatic conditions across North America. They describe a "megadrought" that occurred in Mexico in the 
Fig. 7. Normalized (relative to the full period) time series plot of the Flowerpot chronology over the 610-1989 period, where the expressed population signal statistic (EPS) is $>0.85$ (Wigley et al. 1984). The bold line is a 25-year cubic smoothing spline. The number of extreme (>1.5 SD) annual values are shown above for each 100-year period. Note that the first and last periods (610-699 and 1900 onwards) are not complete 100-year windows. The black bars denote extreme (>1.0 SD) nonoverlapping 10-year periods of above- and below-average inferred summer precipitation (see Table 3 for details).

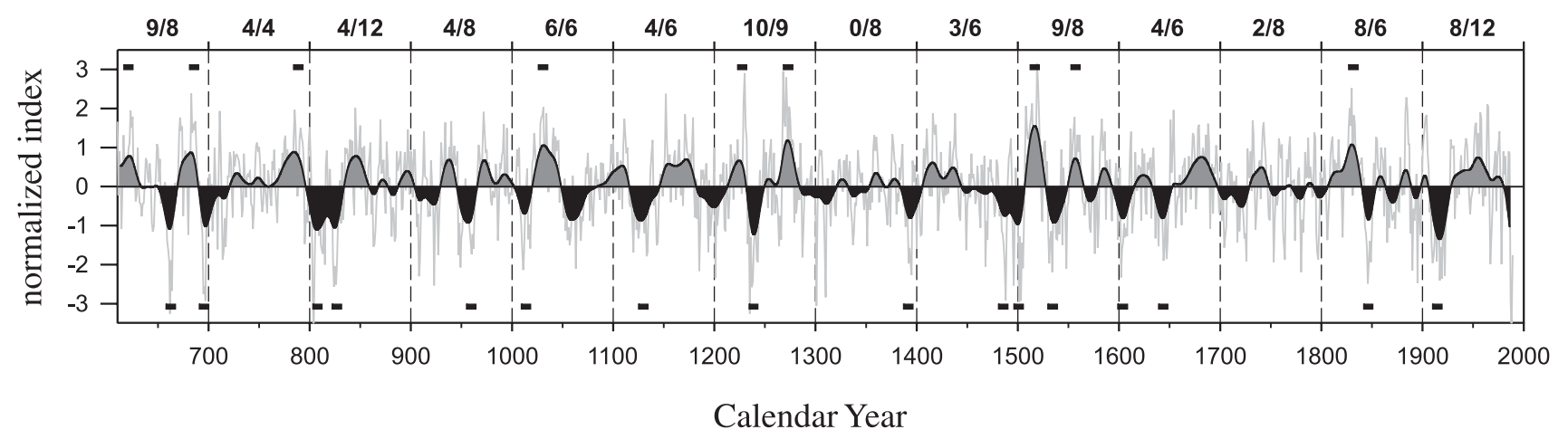

Table 3. Extreme nonoverlapping decadal periods $(>1.0 \mathrm{SD})$ of above- and below-average inferred summer precipitation.

\begin{tabular}{ll}
\hline Decade & Mean decadal deviation \\
\hline Dry & \\
$1234-1243$ & -1.76 \\
$803-812$ & -1.49 \\
$1910-1919$ & -1.48 \\
$1496-1505$ & -1.43 \\
$658-667$ & -1.35 \\
$822-831$ & -1.32 \\
$691-700$ & -1.30 \\
$1842-1851$ & -1.25 \\
$1530-1539$ & -1.18 \\
$1639-1648$ & -1.11 \\
$1599-1608$ & -1.09 \\
$1481-1490$ & -1.05 \\
$1009-1018$ & -1.05 \\
$955-964$ & -1.03 \\
$1387-1396$ & -1.02 \\
$1125-1134$ & -1.00 \\
Wet & \\
$1512-1521$ & 1.76 \\
$1268-1277$ & 1.71 \\
$1827-1836$ & 1.26 \\
$1026-1035$ & 1.14 \\
$681-690$ & 1.09 \\
$616-625$ & 1.08 \\
$1223-1232$ & 1.07 \\
$1552-1561$ & 1.03 \\
$784-793$ & 1.03 \\
\hline
\end{tabular}

Note: The decadal extremes were identified by computing 10 -year means using the nonfiltered normalized data (reference period, 1610-1989).

1560 s and then appeared to spread north and east during the latter half of the 16th century. It is possible that the 15991608 dry decadal period in the FLOW chronology is a weak expression of this northward spread of this 16th century megadrought. The $1827-1836$ wet period, mentioned earlier, is the third wettest decadal period in the entire FLOW record and is itself followed by dry conditions from 1842 to 1851. Despite these climatic oscillations, an earlier study of the population dynamics of cliff-face $T$. occidentalis shows no significant pulses of either recruitment or mortality of the trees in these time periods (Kelly and Larson 1997).

The FLOW chronology portrays a picture of variable hydroclimatic conditions with prolonged decadal periods of either dry or wet conditions that suddenly shift to the opposite extreme. By studying the number of extreme ( $>1.5 \mathrm{SD})$ years in each century (Fig. 7), the centuries that appear to have shown the most variability at interannual time scales are the 7th, 9th, 13 th, and 16 th. The 20th century also shows high year-to-year variability, but the effects of fire and other possible anthropogenic disturbance factors in the early 20th century, coupled with the quantified loss of climate signal fidelity toward the latter half of the century, may be biasing the results.

\section{Conclusion}

This paper reports on a recently expanded network of eastern white-cedar chronologies from southern Ontario, Canada. Seven chronologies have been developed, one of which goes back to 798 вС (Table 1). Applying principal component regression, a June-July precipitation reconstruction (SOR), spatially weighted to southern Ontario, was developed using these data. Although the model explains only $33 \%$ of the climatic variance, it does verify against climate data prior to the calibration period (1900-1960). A weakening in the climate - tree growth relationship was noted in recent decades. At this time, we have no satisfactory explanation for this loss of fidelity in recent decades, but we note a similar weakening in climate - tree growth relationship response of trees of this same species located on the western edge of the Niagara Escarpment cliffs of the Door Peninsula (Fig. 1) in Wisconsin (B.M. Buckley, R.J. Wilson, P. Kelly, and D.W. Larson, unpublished data).

The SOR series presented in this paper shows some coherence at decadal scales with an independent tree-ring-based reconstruction of PDSI (Cook et al. 1999) for southern Ontario. The nearly three-millennial FLOW chronology correlates better with the $\mathrm{COOK}$ series prior to the late 20th 
century than with SOR. Excluding the late 20th century, the combined information of the SOR, COOK, and FLOW series serves as a reasonable proxy for hydrometeorological conditions over the region, and shows that dry conditions existed for the periods $1700-1725,1750-1800$, and 1840 1900 , and generally wet conditions for the periods 1675 1700, 1730-1750, and 1810-1840. The long FLOW chronology was used to infer past hydroclimatic conditions back to AD 610. We have identified several shifts between decadal extremes of dry and wet periods over the past 1400 years, sometimes following closely from one extreme to the other. Summer precipitation was most highly variable during the 7th, 9th, 13th, and 16th centuries.

This study clearly illustrates the importance of these highly unique, long tree-ring records for the study of past climate conditions over the Great Lakes Region. Future work needs to focus on addressing the late 20th-century calibration problems noted in this study. Whether the tree-ring records reflect local ecological effects (e.g., fire or other physical disturbance) or are a product of a larger-scale regional forcing that could be anthropogenic in nature (e.g., pollution effects related to proximity of heavy industry) needs to quantified. If this latter scenario is indeed in effect, the cedar data prior to the 20th century can be interpreted as hydroclimate proxies with more confidence than if the former scenario predominates.

Finally, it is possible that some of the chronologies can be further extended, perhaps to several thousands of years, if we incorporate wood samples found preserved on the talus below the cliffs, as driftwood in paleo-shoreline caves, and on submerged terraces in the lakes themselves (S. Blascoe, personal communication). This last source may result in the development of important information regarding changing lake levels throughout the Holocene (e.g., Lewis and Anderson 1989; Chrzastowski et al. 1991), particularly if the regional coverage of long, moisture-sensitive tree-ring chronologies can be expanded to cover more of the Great Lakes Basin. The composite wood resource along the Niagara Escarpment may ultimately allow for the development of an exactly dated T. occidentalis chronology that spans much of the Holocene. It is this potential that illustrates the global importance of this white-cedar resource.

\section{Acknowledgements}

The authors gratefully acknowledge the National Science Foundation of the United States (ATM 00-00181) Global Forest Science, the Natural Sciences and Engineering Research Council of Canada (NSERC), The Richard Ivey Foundation, EJLB Foundation, Parks Canada, Ontario Parks, Ontario Heritage Foundation, and the Ontario Ministry of the Environment for funding to conduct the fieldwork. Parks Canada, Ontario Parks, and Milton Limestone granted permission to sample trees on their properties. Don Youngblut provided aid in the field. We also wish to thank Dr. Brian Luckman and one anonymous reviewer for their thorough reviews and very helpful comments that added much to this paper. Lamont-Doherty contribution LDEO 6713.

\section{References}

Ahlgren, C.E. 1957. Phenological observations of nineteen native tree species in northeastern Minnesota. Ecology, 38: 622-628.

Archambault, S., and Bergeron, Y. 1992. An 802-year tree-ring chronology from the Quebec boreal forest. Can. J. For. Res. 22: 674-682.

Barber, V., Juday, G.P., and Finney, B. 2000. Reduced growth of Alaskan white spruce in the twentieth century from temperatureinduced drought stress. Nature (Lond.), 405: 668-673.

Brázdil, R., Stepánková, P., Kyncl, T., and Kyncl, J. 2002. Fir tree-ring reconstruction of March-July precipitation in southern Moravia (Czech Republic), AD 1376-1996. Clim. Res. 20: 223-239.

Briffa, K.R. 1995. Interpreting high-resolution proxy climate data: the example of dendroclimatology. In Analysis of climate variability: applications of statistical techniques. Edited by H. von Storch and A. Navarra. Springer-Verlag, Berlin. pp. 77-94.

Briffa, K.R., Schweingruber, F.H., Jones, P.D., Osborn, T.J., Harris, I.C., Shiyatov, S.G., Vaganov, E.A., and Grudd, H. 1998a. Trees tell of past climates: but are they speaking less clearly today? Philos. Trans. R. Soc. Lond. Ser. B, 353: 65-73.

Briffa, K.R., Schweingruber, F.H., Jones, P.D., Osborn, T.J., Shiyatov, S.G., and Vaganov, E.A. 1998b. Reduced sensitivity of recent tree-growth to temperature at high northern latitudes. Nature (Lond.), 391: 678-682.

Brinkman, W.A.R. 1987. Water supplies to the Great Lakes: reconstructed from tree-rings. J. Clim. Appl. Meteorol. 26: 530-538.

Chrzastowski, M.J., Pranschke, F.A., and Shabica, C.W. 1991. Discovery and preliminary investigations of the remains of an early Holocene forest on the floor of southern Lake Michigan. J. Great Lakes Res. 17: 543-552.

Cook, E.R. 1985. A time series analysis approach to tree-ring standardisation. Ph.D. thesis, University of Arizona, Tucson, Ariz.

Cook, E.R., Briffa, K.R., and Jones, P.D. 1994. Spatial regression methods in dendroclimatology: a review and comparison of two techniques. Int. J. Clim. 14: 379-402.

Cook, E., and L. Kairiukstis. 1990. Methods of dendrochronology. Kluwer, Dordrecht.

Cook, E.R., Meko, D.M., Stahle, D.W., and Cleaveland, M.K. 1999. Drought reconstructions for the continental United States. J. Clim., 12: $1145-1162$.

Cook, E.R., and Peters, K. 1997. Calculating unbiased tree-ring indices for the study of climate and environmental change. Holocene, 7: 361-370.

Environment Canada and US Environmental Protection Agency. 1995. Great Lakes atlas. 3rd ed. Environ. Canada and US Environmental Protection Agency, Toronto and Chicago.

Eriksson, M. 1989. Integrating forest growth and dendrochronological methodologies. Ph.D. thesis, University of Minnesota, Twin Cities, Minn.

Esper, J., Cook, E.R., and Schweingruber, F.H. 2002. Low-frequency signals in long tree-ring chronologies for reconstructing past temperature variability. Science (Washington, D.C.), 295: 22502253.

Fichtner, K., Koch, G.W., and Mooney, H.A. 1994. Photosynthesis, storage, and allocation. In Ecophysiology of photosynthesis. Edited by E.D. Schulze and M.M. Caldwell. Springer-Verlag, Berlin. pp. 133-146.

Forster, T., Schweingruber, F.H., and Denneler, B. 2000. Increment puncher. A tool for extracting small cores of wood and bark from living trees. IAWA J. 21: 169-180.

Fritts, H.C. 1976. Tree rings and climate. Academic Press, London. 
Hulme, M. 1992. A 1951-80 global land precipitation climatology for the evaluation of General Circulation Models. Clim. Dyn. 7: $57-72$.

Hulme, M. 1994. Validation of large-scale precipitation fields in General Circulation Models. In Global precipitations and climate change. Edited by M. Desbois and F. Desalmand. NATO ASI Series. Springer-Verlag, Berlin. pp. 387-406.

Jacoby, G.C., and D'Arrigo, R. 1989. Reconstructed northern hemisphere annual temperatures since 1671 based on high-latitude tree-ring data from North America. Clim. Change, 14: 39-59.

Jacoby, G.C., and D'Arrigo, R. 1995. Tree ring width and density evidence of climatic and potential forest change in Alaska. Global Biogeochem. Cycles, 9: 227-234.

Jones, P.D. 1994. Hemispheric surface air temperature variations: a reanalysis and an update to 1993. J. Clim. 7: 17.

Jones, P.D., and Hulme, M. 1996. Calculating regional climatic time series for temperature and precipitation: methods and illustrations. Int. J. Clim. 16: 361-377.

Kelly, P.E., Cook, E.R., and Larson, D.W. 1992. Constrained growth, cambial mortality, and dendrochronology of ancient Thuja occidentalis on cliffs of the Niagara Escarpment: an eastern version of bristlecone pine? Int. J. Plant Sci. 153: 117-127.

Kelly, P.E., Cook, E.R., and Larson, D.W. 1994. A 1397-year treering chronology of Thuja occidentalis from cliff-faces of the Niagara Escarpment, southern Ontario, Canada. Can. J. For. Res. 24: 1049-1057.

Kelly, P.E., and Larson, D.W. 1997. Dendrochronological analysis of the population dynamics of an old-growth forest on cliff-faces of the Niagara Escarpment, Canada. J. Ecol. 85: 467-478.

Larson, D.W., and Kelly, P.E. 1991. The extent of old-growth Thuja occidentalis on cliffs of the Niagara Escarpment. Can. J. Bot. 69: $1628-1636$.

Larson, D.W., Matthes, U., and Kelly, P.E. 2000. Cliff ecology: pattern and process in cliff ecosystems. Cambridge University Press, Cambridge, UK.

Lewis, C.F.M., and Anderson, T.W. 1989. Oscillations of levels and cool phases of the Laurentian Great Lakes caused by inflows from glacial Lakes Agassiz and Barlow-Ojibway. J. Paleolimnol. 2: 99-146.

Lloyd, A.H., and Fastie, C.L. 2002. Spatial and temporal variability in the growth and climate response of treeline trees in Alaska. Clim. Change, 52: 481-509.

Matthes-Sears, U., and Larson, D.W. 1991. Growth and physiology of Thuja occidentalis L. from cliffs and swamps: is variation habitat or site specific? Bot. Gaz. 152: 500-508.

Matthes-Sears, U., Nash, C.H., and Larson, D.W. 1995. Constrained growth of trees in a hostile environment: the role of water and nutrient availability for Thuja occidentalis on cliff faces. Int. J. Plant Sci. 156: 311-319.

Matthes-Sears, U., Stewart, S.C., and Larson, D.W. 1991. Sources of allozymic variation in Thuja occidentalis in southern Ontario, Canada. Silvae Genet. 40: 100-105.
Mekis, E., and Hogg, W.D. (1999). Rehabilitation and analysis of Canadian daily precipitation time series. Atmos. Ocean, 37: 53-85.

Nicholls N., Gruza G.V., Jouzel J., Karl, T.R., Ogallo L.A., and Parker D.E. 1995. Observed climate variability and change. In Climate change 1995: the science of climate change. Edited by J.T. Houghton, L.G. Meira Filho, B.A. Callander, N. Harris, A. Kattenberg, and K. Maskell. Contribution of Working Group 1 to the second assessment report of the IPCC. Cambridge University Press, Cambridge University Press, Cambridge, UK.

Osborn, T.J., Briffa, K.B., and Jones, P.D. 1997. Adjusting variance for sample size in tree-ring chronologies and other regional mean timeseries. Dendrochronologia, 15: 89-99.

Parker, D.E., Folland, C.K., and Jackson, M. 1995. Marine surface temperature: observed variations and data requirements. Clim. Change, 31: 559-600.

Richman, M.B. 1986. Rotation of principal components. J. Clim. 6: 293-335.

Stahle D.W., Cook, E.R., Cleaveland, M.K., Therrell, M.D., Meko, D.M., Grissino-Mayer, H.D., Watson, E., and Luckman, B.H. 2000. Tree-ring data document 16th century megadrought over North America. Eos, 81: 121-125.

Stokes, M.A., and Smiley, T.L. 1968. An introduction to tree-ring dating. University of Chicago Press, Chicago, Ill.

Tardif, J., and Bergeron, Y. 1997. Comparative dendroclimatological analysis of two black ash and two white cedar populations from contrasting sites in the Lake Duparquet region, northwestern Quebec. Can. J. For. Res. 27: 108-116.

Tardif, J., and Stevenson, D. 2001. Radial growth-climate association of Thuja occidentalis L. at the northwestern limit of its distribution, Manitoba, Canada. Dendrochronologia, 19: 1-9.

Trenberth, K. 1984. Some effects of finite sample size and persistence on meteorological statistics. Part I. Autocorrelations. Mon. Weath. Rev. 112: 2359-2368.

Vaganov, E.A., Hughes, M.K., Kirdyanov, A.V., Schweingruber, F.H., and Silkin, P.P. 1999. Influence of snowfall and melt timing on tree growth in subarctic Eurasia. Nature (Lond.), 400: 149-151.

Walker, G.L. 1987. Ecology and population biology of Thuja occidentalis L. in its southern disjunct range. Ph.D. thesis, University of Tennessee, Knoxville, Tenn.

Waring, R.H. 1987. Characteristics of trees predisposed to die. Bioscience, 37: 569-573.

Wigley, T.M.L., Briffa, K.R., and Jones, P.D. 1984. On the average of correlated time series, with applications in dendroclimatology and hydrometeorology. J. Clim. Appl. Meteorol. 23: 201-213.

Wilson, R.J.S., and Luckman, B.H. 2003. Dendroclimatic reconstruction of maximum summer temperatures from upper treeline sites in interior British Columbia. Holocene, 13: 853-863.

Wilson, R.J.S., and Elling, W. 2004. Temporal instabilities of treegrowth/climate response in the Lower Bavarian Forest Region: implications for dendroclimatic reconstruction. Trees (Heidelb.), 18: 19-28. 